\title{
The Practice of Traditional Rituals in Naga Aradhana (Snake worship): A Case study on Aadimoolam Vetticode Sree Nagarajaswami Temple in Kerala, India
}

\author{
Dinu Das ${ }^{1}$, and Arumugam Balasubramanian, ${ }^{2, *}$ \\ 1,2 Department of Communication, Coimbatore, Amrita Vishwa Vidyapeetham University, Tamil \\ Nadu, India
}

\begin{abstract}
Snakes are worshiped in different parts of the world based on the culture and traditions. Snake worship is a part of Hindu religion and plays an important role in cultural as well as in ritual aspect in India. This study explores the ritual practices in Naga aradhana in the Indian state Kerala, by taking Aadimoolam Vetticode Sree Nagarajaswami temple as a case study. This paper aims to understand the importance of Naga aaradhana and the practice of rituals related to Naga Dosha (curse of snakes), like Kalamezhuthu, Pulluvanpaatu, Sarpamthulal, Sarpabali, the annual festival Ayilyam Mahotsavam and the importance of Sarpakaavu (sacred groove) in the temple. This research is conducted using the methodology of personal interviews and video analysis. This study concludes that the Sarpakavu has a unique meaning and believers from different caste and religion have respect and admiration for this divinity.
\end{abstract}

\section{Introduction}

Snakes are animals that fascinate many people while frightening others. Good or bad, most people have strong feelings about snakes, but few people remain neutral [11]. The rituals devoted to the propitiation and supplication of the sarpa, as the common snake is called in Sanskrit, as well as the snake's supernatural counterpart the Naga are present in the Indian sub-continent for more than two millennia [9].Worship of the Snake Gods (Naga) has taken a prominent place in various forms of literature, traditional paintings, art, sculpture, folklore, architecture and so on. The ancient civilizations throughout the world treated Naga's as a part of society. The snake therefore can be seen in old traditional cultures where snakes are the entities of strength and renewal. There are different kinds of festivals associated with Naga/snake throughout India. In northern India king of snakes, Nagaraja is worshiped whereas in southern India; the snakes are worshiped as whole.

Snakes are considered as demigod in the southern India, especially in Kerala. People in Hindu religion worship Snakes in temples and in their natural habitats. The devotees offer snake god with milk, incense, and prayers. In Hindu rituals and spiritual tradition, the

*Corresponding author: a balasubramanian@cb.amrita.edu 
snakes represent divinity, eternity, materiality, life and death, and time as well as timelessness. It symbolizes the three processes of creation, namely creation, preservation and destruction [8]. Throughout Kerala there are temples devoted to snake worship. The major temples are Mannarsala, Vettikode, Pambumekkatu mana, Pulikal Shankaramadam, Pambady Nagaraja Temple, Kumaranalloor Nagaraja Temple and Madanmarukavu Nagaraja temple in Alanadu. The presence of these temples and the number of devotees visiting these temples point to the deep rooted spiritual beliefs and religious values related to snake worship. This religious tradition in Kerala is directly connected to the ancient mythology and literature of Hinduism in India.

The ancient literature and the epics like Mahabharata and Ramayana give ample documents on the Nagas. The characterization of Naga in art is common during the historical period. It is hard to track down when and how Naga aradhana began in Kerala. Mythology through Keralolpathi, a history of Kerala points to the period when Brahmins settled in Kerala after the lord Parasurama. On the request of Brahmins, Parasurama allotted a different residential area for the Nagas to eliminate troubles they might cause to human beings [2], [3]. In Hindu mythology Nagas play a prominent role, through various legends. Shesha also called as Aadi shesha or Ananda is the snake on whom lord Vishnu does his Yoga nidra (sleep), otherwise called as Ananda shayana. The snake Vasuki is considered to be the king of Nagas, who allowed demons and gods to use her body as a rope to bring out the elixir for saving people. The Lord Shiva, the god of gods wears a snake around his neck. It is believed that Shiva has given an important place for Nagas.

Several researchers have conducted studies on Snake and snake worship in India and also in other countries. A researcher pointed out that the Snakes, Goddesses, and Women's Ritual Responses in Contemporary South India have a focus on the rituals in an Amman temple of Tamil Nadu [1]. Ethnographic study conducted on snake (naga) worship and traditions associated with naga doșam (snake blemish) are also an important aspect in the study. It studies the astrological flaw related to delay in marriage, skin diseases, infertility in women and children born with low intelligence and autism.

In India, there are families who worship the Naga as their family god and have monument around their home and sometimes even inside their home. The families devoted to Naga worship thus follow rituals to please the snake God. A researcher pointed out how snake worship and protection of the environment correlates to one another and also about different varieties of snakes present in Kerala [4].

\section{Aadimoolam vetticode sree nagarajaswami temple}

Aadimoolam Vetticode Sree Nagarajaswami Temple is located near Kayamkulam in Alappuzha district of Kerala. Hindu mythology says that, Sree Nagaraja Swami Temple was consecrated by Lord Parasurama. The temple was built as a gratitude to Anantha, the snake god, who asked to suck out the unwanted elements in Kerala to turn it into a fertile land for the residents. The temple is located on a six-acre land with a Sarppakavu (sacred groove) which has Nagaraja and Nagayakshi as principal deities. The temple has Sri Parameswaran Nampoothiris as the Karanavar (chief), who has devoted his life to Naga Aaradhana. The temple, devoted to snake worship, practices certain rituals and traditions.

The major reason for practicing these rituals is Naga Dosha or curse of snake. Naga dosha is caused when a person knowingly or unknowingly hurts a snake or destroys the place where they reside. The personal interview with the philosopher Madhav Sreekumar and Astrologer Joseph Nedumkandam related to a general concept that Naga dosha means anger of God. For getting rid of Naga dosha people practice various pooja or offerings in the Temple. The major rituals are Sarpabali, Sarpamthulal along with Kalamezhuthu and Pulluvanpaatu. Sarpabali is conducted using a sketch or Kalam drawn for Naga Raja (snake 
god) on the day of Aayilyam ( a zodiac sign according to Malayalam calendar) and the priest performs various offerings along with religious chants. Sarpamthulal is a long procedure and happens near the sacred groove inside the temple compound. In this ritual a sketch is drawn on the ground based on the need of pooja. Pulluvanpaatu, the hymns by a tribe devoted to Nagas, sing songs to please and invite Naga god into the sketch. It is said that the Pulluvanpaatu reaches the heaven where the Naga Gods reside. Young virgin girls receive the soul of Naga god during the procedure and talks to people and try to redeem them from curse of snake. Later these people clear the sketch and conclude the pooja.

The temple also offers various other rituals to cure minor Naga dosha based on astrological calculations, it includes Ashta Naga pooja, Dhara, Aadiya Enna, Uruli Kamezhuthu and Rahur Dasha shanti. Ashta Naga pooja, is to please the eight major snake gods. Dhara is an offering for both Nagaraja (the king of snake God/ anantha) and Nagayakshi (the queen of snake god) using an abhisheka jala (sacred water). Aadiya enna is an offering where devotees give bath to the snake deities using gingely oil, mainly to cure skin disease. Uruli Kamezhuthu is carried out by married couple who are childless. In this they keep a round vessel called Uruli in reverse position in front of Nagaraja. The rahur dasha shanti is for clearing the Naga dosha in the astrological calendar.

The following are the objectives of this study:

- To understand the significance of Naga (snake worship) culture and rituals.

- Study of Sarppakkavu or Sacred groves for Snakes with relation to the Naga aradhana and Snake song, Pulluvanpattu.

\section{Methodology}

To study the practice of traditional rituals in Naga aradhana, the qualitative method has been considered where personal interviews along with visual documentation are the tools taken for collecting data. For the personal interview, priests, astrologers, anthropologists and believers belonging to different caste and religion were selected. The process of data collection was spread over three months. During the in-depth interview, the researchers encouraged the participants to describe their belief, experience and what they found exciting about the traditional rituals in Naga aradhana. All the in-depth interviews were conducted one-on-one and visually documented. Visuals were viewed and the important segments to the interview questions were transcribed.

\section{Analysis \& interpretation}

Every religion has rituals and it varies according to the traditional and cultural beliefs. The Naga worship in Aadimoolam Vetticode Sree Nagarajaswami temple is a proof for the existence of primitive culture of snake worship in Kerala. The legend of Parasurama and the oral culture transferred through the Karanavar (chief) of the temple, points to the fact that this temple is the first temple built for snake worship by Lord Parasurama. There is also a legend stating that Lord Parasurama himself created the idol of snake god, Anantha out of a rock using his axe. This temple is maintained by the traditional family called Meppallil Illam. The Chief of temple, Parameswaran Nampoothiri is the head of that family.

According to the astrologer Joseph Nedumkandam, Naga is considered to be the manifestation of nature and psychological quality of intelligence in Hinduism. Therefore Naga Aaradhana or snake worship is worshiping the nature and also the intelligence. The head priest of Nagarajaswami Temple said that, in India people worship Nagas because of the fear that they are capable to bless and curse. 


\subsection{Naga dosha}

The curse of Naga is called as Naga dosham. Naga dosham in general according to astrologer Joseph is the anger of snake god. The head priest defined the reason for Naga dosham as harming Nagas or any sacred object related to snake worship. Another aspect of sarpadosha according to astrologer Joseph is associated to the harms against the earth, like digging or cutting of trees and plants. This is associated to another myth related to Adisesha, personification of force which keeps earth stable along the path way of sun. The Naga dosham causes health problems like white patches on skin, belated marriage and pregnancy, eye disease, handicapped or disabled birth, unnecessary dispute and quarrel among family members and other incurable diseases. The temple offers various rituals (poojas) as a solution to get rid of Naga dosham.

\subsection{Sarpabali}

Sarpabali is the ritual of worshiping Lord Nagaraja or Anantha on Ashlesha Nakshatra ( an Indian Zodiac star) otherwise called as Ayyilyamstar. Sarpabali is performed to appease Ashta Nagas and to fend off evil effects of Sarpa dosha (curse of snake). As part of Sarpabali, a colorful sketch of Padma (Lotus) is drawn on the ground of the temple. In the middle portion there is Ashtadala (eight petals) and its outward triangle represents nature and Man. The upward and downward triangles of ashtadala indicate the close association between nature (prakrithi) and man (Purusha). The extreme outer part of the sketch has Sarpakettu. This again is in a lotus shape. The padma(lotus) for the sarpabali can be seen only from that point. The priest offers prayers and sacrifices (bali) to please naga through various mantras and chants near this sketch for the people having Naga dosha. The people who witness this holy performance will redeem themselves from the anger of Nagas.

\subsection{Ashta Naga pooja}

The ashta naga pooja is a special ritual performed for ashta Nagas (eight snakes). The main eight snakes are Anantha, Gulika, Vasuki, Shankapala, Thakshaka, Mahapadma, Padma and Karakodaka. The pooja offers Noorum Paalum through Thelichukuda ritual to each snake deity separately. The Noorum paalum includes ingredients like, tender coconut, fresh milk of cow, rose water, turmeric and the seeds of tender coconut (pookula). The juice of these ingriedients together is called as Noorum Paalum.

\subsection{Rahur dasha Shanti}

The poojas or rituals related to Sarpa dosha changes according to the astrological aspects of a human and the severity of the anger of snake god. The other poojas (rituals) related to Naga dosha includes Rahur dasha Shanti. The ritual concentrates on offerings to get rid of all diseases and ailments due to the presence of Nagas in Rahu dasha (considered to be the worst time according to the Hindu astrological calendar).

\subsection{Dhara}

The ritual Dhara, (pouring sacred water on the devotees) is another ritual for Sarpa dosha. The ritual's main element is Abhisjeka Jala (the sacred water). It is a special offering to the main deities, Nagaraja and Nagayakshi. The Abhisheka Jala or dhara is made out of tender coconut water, milk and plain water. This water is poured on people with Naga dosha. 


\subsection{Uruli Kamizhthu}

The ritual is conducted for people without children due to the anger of snake gods. The couples with faith purity in mind will undertake this ritual. The ritual starts with Pradikshana(circling the main temple of snake God Anantha) and Namajapa (chants) with Panchavadyamelam (music created using five temple musical instruments). The couples carry a Uruli (wok) covered with red coloured silk cloth in front of the idol of Nagayakshi (diety). They later come to the idol of Nagaraja for the act of Uruli Kamzhithu (turning the wok upside down). The nivedya (banana and milk) is offered to both the deities for their blessing. After the birth of child, the couple need to come back and perform Uruli Nivarthu (turning the wok upwards) with the child.

\subsection{Aadiya enna}

Aadiya enna (bath to deities using gingely oil) is another ritual for people suffering from skin disease. The deity Nagaraja is given a bath using gingelly oil on Brahma Muhurtha (auspicious time) to get rid of skin disease caused by Sarpakopam (anger of snake god).

\subsection{Sarpamthulal}

Sarpamthulal is prerformed in this temple during the day of Ayilyam star in Malayalam calander. The ancient legend of Nagas in Kerala according to the astrologer Padmanabhan Sharma narrates that Nagas who were the masters of forests left their home and moved to a narrow area (sacred grooves) for the peaceful life of humans. Thus once in a while based on the astrological calendar, the snake devotees perform Sarpamthulal to reveal the gratitude towards snake gods and also to seek their blessings. The Sarpamthulal includes rituals like Kalamazhuthu and Pulluvan paatu. In the temple they perform Sarpamthulal for the Ashta Nagas. The sarpapattu is a spiritual dance performance done by the devotees who get incarnated with the soul of eight snake gods during the holy ceremony. The Sarpamthulal is performed nearby sacred groove (Sarpakaavu) inside the temple compound.

The ceremony starts with Kalamezhuthu. Kalams are the combination of two dimensional and three dimensional designs drawn on the floor using fine powder extracted from nature [13]. The colours extracted from fruits are used to draw sketches related to snakes. Through these sketches, snakes are invited into the pooja (sacred ritual) through various chants and prayers. The sketches of snake vary from the need for Pooja. In the temple we can see the sketch related to Ashta Naga. For the ashta naga sketch, they used five natural colours. They are white (rice flour), red (dry saffron's powder), yellow(turmeric powder), green( the powder of leaves) and black (the powder from burned rice barks). The colours are added to the sketch drawn out of white powder (rice flour). The drawing is done using hands and the art of shading, especially the background which gives a velvet touch. Combinations and permutations are used for foregrounding or to create illusions. The later addition is the influence of oil lamps around the Kalam where rituals are known as thiri uzhichil, a form of worship [13]. The Ashta naga sketches include the sketches of Nagaraja ( snake god), Nagayakshi, Anjanamani Nagam, Mani Nagam, Para Nagam and Kari Nagam. After finishing the sketch the Pulluvans start their hymns and invite the tridevs in Hinduism, that is Lord Brahma,Lord Vishnu and Lord Shiva.

Later the pulluvans start singing hymns for deities including snake gods and other deities to invite the snake gods. The songs illustrate the myth behind the Naga accompanied with unique instrument called Pulluva Veena .A virgin girl waits with a Pookula in her hand to receive the soul of Snake god in her body. After a while the virgin receives the soul and starts the spiritual dance called as Sarpamthulal. The energy passed on to the girl 
through the soul makes the virgin to appear supernatural and powerful. The virgin later blesses the devotees and redeem the people from the curse of snakes. Last stage is called Kalam Mayickal. In this stage the virgin erases the sketch drawn on the floor and the pooja gets completed.

\subsection{Pulluvan Pattu}

The Pulluvan Patti is the praising hymns sang by Pulluvans. Pulluvans are people dedicated to sing hymns and songs for snake gods in Kerala. Vinayakan Nampoothiri said that Pulluvans Paatu reaches the eternal world of snakes. These people are the predecessors in snake worshipers in Kerala. Pulluvans travel from house to house and sing hymns for naga during the Malayalam month of Kanni and Makaram to cure Naga Dosha [14]. They sing hymns for the Lord Anantha and all other Nagas along with the assistance of musical instruments including Veena and Kudam (Pot). The one stringed violin known as the Pulluvan veena, the Pulluvan kudam, an earthen pot with a string fastened to it, Pulluvan mizhavu and cymbals. Out of these, the Pulluvan veena plays a major part during the rituals. The music produced with the combination of this hymns and musical instruments of the Pulluva community praise 'holy serpents' such as Ananthan, Manimudgaran, Adiseshan and Mahapadman. The pulluvan Paatu is a major element and is one of the major worship practices of Naga called Sarpamthulal.

\subsection{Ayiliya Mahotsavam}

Another important aspect of this temple is the annual Ayiliya Mahotsavam festival. The festival is performed on the Ayiliyam day of Malayalam month Kanni. The celebrations start seven days prior to the Ayiliyam day. There are various rituals and traditions associated with the festival, which will be carried out during these days. This is performed to increase the power of deity and to shower blessings on the devotees. The Nadabhrama with instruments like Kombu and Kuzhal (wind instruments) and Nadaswara instruments like Maddallam, Chenda, Edakka and the Thakil will be played to please the deities. This is followed by Sarpabali and Ezhunnalathu (procession). The procession starts from temple to Meppalil Illam then back to temple after certain poojas in the Illam. The significance of procession is that it distributes and spreads blessing across the way to thousands of devotees witnessing it. Later a sarpabali will be conducted in the temple for the devotees with sarpa dosha or sarpa kopam. The temple remains closed till Brahma Muhoortha and after that Shudhi Kriyas (Purification rituals) the festival is concluded with the Dhaara (pouring sacred water on deities).

\subsection{Sacred grooves/Sarpakaavu}

Kavu in Malayalam vernacular language means a garden or a group of trees. The sacred groves which are dedicated to the snake deities are called Sarpa kavu. Sacred grooves are maintained nearby temples and also in the families of Naga devotees. In the sacred grooves, Chithrakoodu kallu ( a specially designed stone) is the ideal of Naga God. The Sarpa Pooja or offerings for Naga god will be conducted on the day of Aayilyam Star according to malyalam calendar. Naga devotees carry out the traditional Ayiliyam diet and conduct the pooja to please Naga gods [14]. Sarpa kaavu according to the priest Rajan namboothiri maintains the ecological balance. The predecessors cut down the forest for agriculture and therefore attacke the ecosystem as a whole. So they preserved a part of land allotted for Naga gods to maintain the environmental balance and also for the Snake gods. The sacred 
grooves are blessed with a wide variety of trees and medicinal plants. It is also said to be a major source for underground water

\section{Conclusion}

In India people worship. Naga is considered to be the manifestation of nature and psychological quality intelligence in Hinduism. Offerings in this temple are given only once in a year in the Malayalam month of Thulam. The Sarpakavu has a unique meaning and believers from different caste and religion have respect and admiration for this divinity.

\section{References}

1. A.Allocco,. RSAR, 7 (2013)

2. S.Achyuthavaryar, Kerala Samskaram, Thiruvananthapuram Kerala Bhasha Institute, (2008)

3. K.K.N. Kurup, Aryan and Dravidian Elements in Malabar Folklore. Trivandram: Kerala Historical Society, (1977)

4. M.Suresh, Sarpparadhanayum Prakriti Samrakshanavum, (2000).

5. K.Murugan, V.Ramachandran, K.Swarupanandan, M.Remesh, Ind. J. Trad. Know., 7, 455-462,(2008)

6. R.Bala, Snake Worship in Kerala In R. M. Sarkar, Through the Vistas of Life and Lore Folkloric Reflections on Traditional India, Calcutta: Punthi Pustak. (1946).

7. J.P.H. Vogel, Indian Snake Lord or the Nagas in Hindu Legend and Art. Delhi: AES Books. (1998)

8. J. V, The Symbolism of Snakes and Serpents in Hinduism retrieved from. http://hinduwebsite.com/buzz/symbolism-of-snakes-in-hinduism.asp

9. Laurie Cozad. (2004). DG, 2.

10. Jones.G, OJR RSRO, 89-119, (2010)

11. J.W. Gibbons, M. E. Dorcas, Snakes of the southeast. Athens, GA: University of Georgia Press.(2005)

12. J.W. StanleyOMICS 2(2):42-58. (2008).

13. Jayaraj. P, Kalamezhuthu: A ritual performance, (2010) retrieved from http://www.narthaki.com/info/articles/art280.html

14. M.V. Vishnunamboothiri, Pulluvapattum Nagaradhanayum, (National book stall, Kottayam. (1977)

15. E. Thurston - Castes and Tribes of South India, Cosmo Publications, Delhi. (1970) 